\title{
GEOLOGY AND MINERAL RESOURCE POTENTIAL OF THE RICHLAND CREEK ROADLESS AREA, NEWTON AND SEARCY COUNTIES, ARKANSAS
}

\author{
By \\ Mary H. Miller, U.S. Geological Survey, \\ and
}

R. H. Wood II, U.S. Bureau of Mines

\section{STUDIES RELATED TO WILDERNESS}

Under the provisions of the Wilderness Act (Public Law 88-577, September 3, 1964) and the Joint Conference Report on Senate Bill 4, 88th Congress, the U.S. Geological Survey and the U.S. Bureau of Mines have been conducting mineral surveys of wilderness and primitive areas. Areas officially designated as "wilderness," "wild," or "canoe" when the act was passed were incorporated into the National Wilderness Preservation System, and some of them are presently being studied. The act provided that areas under consideration for wilderness designation should be studied for suitability for incorporation into the Wilderness System. The mineral surveys constitute one aspect of the suitability studies. The act directs that the results of such surveys are to be made available to the public and be submitted to the President and the Congress. This report discusses the results of a mineral survey of the Richland Creek Roadless Area (08001), Ozark National Forest, Newton and Searcy Counties, Arkansas.

\section{MINERAL RESOURCE POTENTIAL SUMMARY STATEMENT}

Richland Creek Roadless Area is in the Ozark National Forest in Newton and Searcy Counties, north-central Arkansas. Minor quantities of zinc and lead were produced from faults and fractures in the Boone Formation in the Cave Creek district, about $3 \mathrm{mi}$ north of the area; however, there is no known record of mineral production from within the area.

The Boone Formation crops out in the northwestern part of the mapped area and underlies the entire roadless area. Elsewhere in northern Arkansas, zinc and lead have been produced from the Everton Formation; presumably the Everton lies buried from about 800 to $1,500 \mathrm{ft}$ below the surface of the Richland Creek area. Both the Boone and the Everton Formations have some potential for zinc and lead deposits; however, their presence in the area can neither be confirmed nor ruled out without deep exploratory drilling. Based on available information, potential for zinc and lead is low.

Most of the area is under lease for oil and gas; two wells drilled near the eastern boundary of the area did not show contained gas. There is a low potential for oil and gas. The Fayetteville Shale and shales from the middle Morrowan unit are somewhat petroliferous; however, Fischer assays of selected shale samples do not indicate commercial oil concentrations (Haley and others, 1980). Potential for shale oil is low.

\section{INTRODUCTION}

Location and topography

The Richland Creek Roadless Area covers about 8,620 acres of the Ozark National Forest in Newton and Searcy Counties in north-central Arkansas. The area (see fig. 1) is about $34 \mathrm{mi}$ north of Russellville, Ark., and about 6 mi east of Lurton, Ark.

Access to the northern, western, and eastern borders of the area is by U.S. Forest Service roads. On the south, access is by trail from U.S. Forest Service roads. Nearly all the area is densely timbered. It is cut by Richland Creek and Falling Water Creek and their tributaries.

Elevation in the area ranges from about $1,120 \mathrm{ft}$ along Falling Water Creek in the southern corner to about $2,000 \mathrm{ft}$ on Big Middle Ridge in the northern part. Beds of the upper Morrowan Series form resistant caps on higher hills.

The map (see fig. 2) covers the areas of Richland Creek Roadless Area and Richland Creek Wilderness Study Area (Haley and others, 1980). Sample localities shown on the map are from the wilderness study area and the roadless area.

\section{SURFACE GEOLOGY}

The lowermost formation exposed in the vicinity of the Richland Creek Roadless Area is the Boone Formation of Early and Late Mississippian age. The Boone unconformably overlies truncated rocks of Silurian and Ordovician age. The Boone crops out along the East Fork Cave Creek and along Dry Creek in the northern part of the mapped area but outside the roadless area. It is about $375 \mathrm{ft}$ thick and consists 


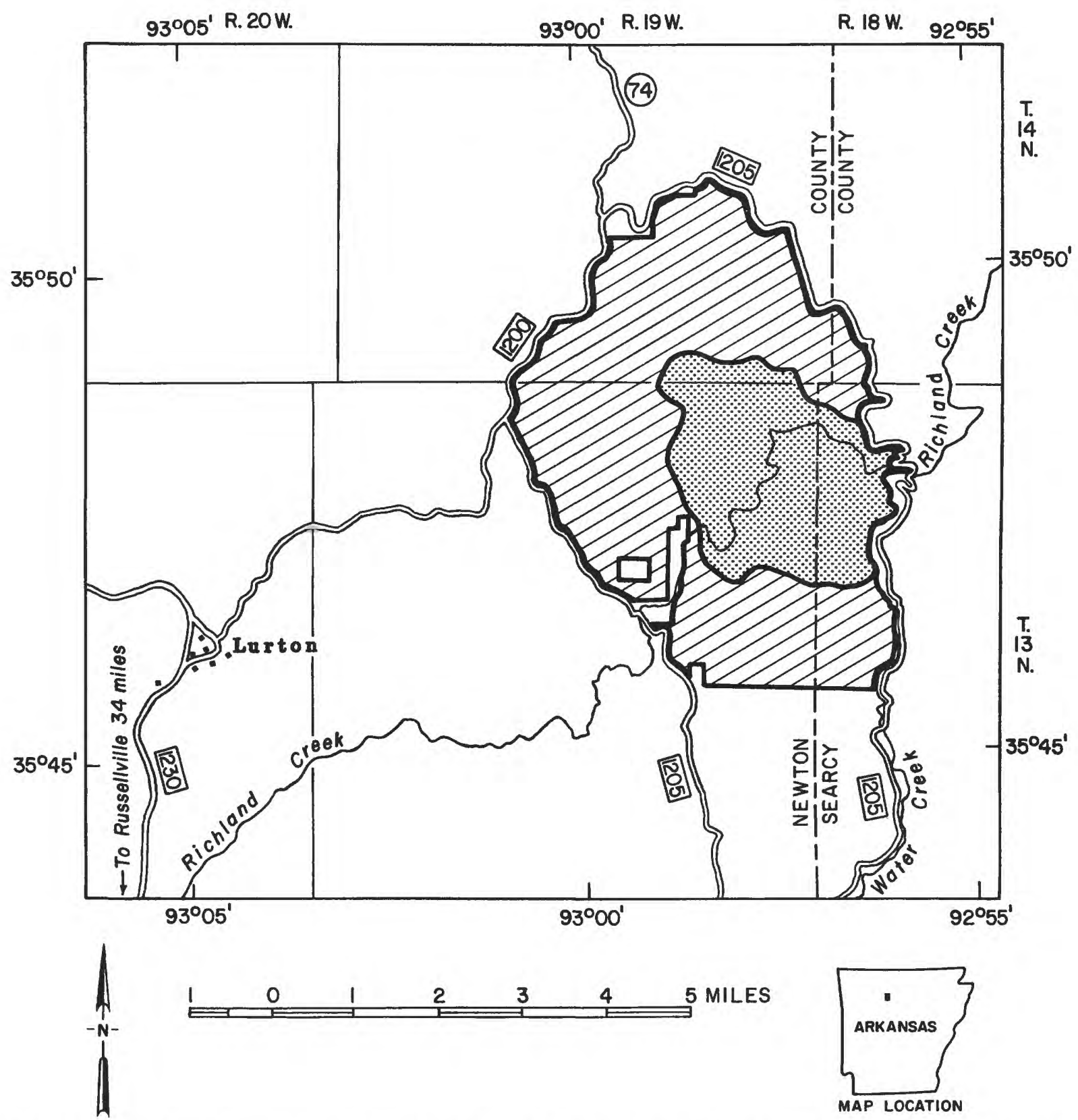

Figure 1.--Index map showing Richland Creek Roadless Area (1ined) 08001 and Richland Creek Wilderness Study Area (stippled), and nearby geographic features, Newton and Searcy Counties, Ark. 


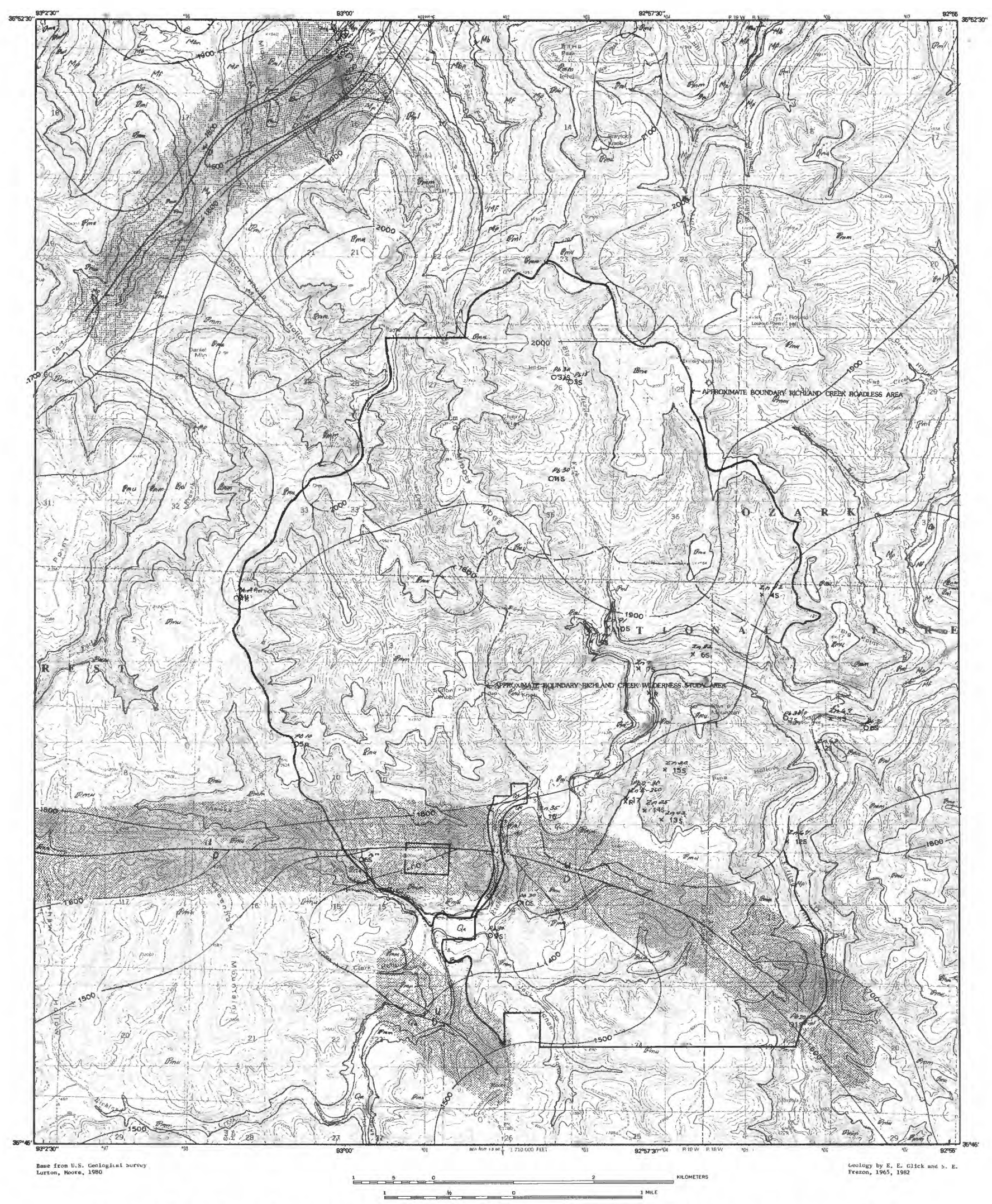

Figure 2.--Map showing geology and areas of mineral resource potential of Richland Creek Roadless Area. 
CORRELATION OF MAP UNITS

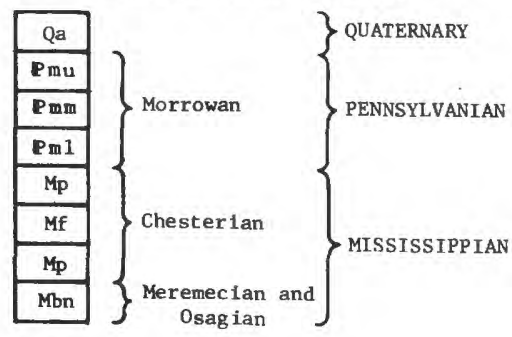

DESCRIPTION OF MAP UNITS

Qa

\section{Pmu}

$\mathbb{P}$ mm

PmI

Mp

Mf
ALLUVIUM (QUATERNARY)--Terrace and valley-fili deposits. Major constituents clay, silt, very fine sand, and gravel; material mapped includes colluvium, alluvium, alluvial-fan deposits, and dissected terrace deposits

MORROWAN SERIES (MIDDLE AND LOWER PENNSYLVANIAN)

Upper--Crossbedded, massive, fine- to coarsegralned sandstone un1t underlies flat upland area; sandstone, shale, and siltstone that make up upper beds of this unit locally contaln crinold stems. Lower sandstone unit contalns quartz pebbles. Thickness about $200 \mathrm{ft}$

Middle--Upper 250-300 ft of the middle Morrowan made up of dark-gray shale and fine- to medium-grained, massive, crosslaminated, glauconit1c, $11 \mathrm{my}$ sandstone; locally grades 1nto sandy 11mestone. Layers commonly contain quartz pebbles and marine foss1ls. Basal unit complex channel fill of conglomerate, sandstone, and shale $100 \mathrm{ft}$ thick. Thickness of unit 250-600 ft

Lower--Sandstone, 11mestone, and interbedded shale make up the lower part of the Morrowan. Upper 100-200 ft is dark-gray silty shale; contains layers of clay Ironstone and a few plant fossils. Th1 ckness ranges from 0 to $340 \mathrm{ft}$

PITKIN LIMESTONE (MISSISSIPPIAN)--Med1 um-gray massive 11 mestone containing a few beds of dark-gray limy shale; crops out in cliffs and steep slopes in northern and eastcentral parts of area. Upper and middle beds contain abundant oolltes. Lower beds grade upward into poorly exposed medlum-gray Iimy shale and a few beds of I1mestone, which are silty in part; locally contain fine quartz grains. Bryozoans, crinolds, brachlopods, pelecypods, and corals are common throughout formation. Total thickness about $230 \mathrm{ft}$

FAYETTEVILLE SHALE (MISSISSIPPIAN)--Ninety percent dark-gray shale and 10 percent darkgray microcrystalline petroliferous limestone. Upper half of formation, mainly limestone, contains brachlopods, bryozoans, and crinolds; lower half of formation, predominantly shale, contains conodonts and pelecypods; middle and upper units of formation phosphatic. Thickness about 180-220 ft
Mb

BATESVILLE SANDSTONE (MISSISSIPPIAN)--L1ght- to medium-gray, silty, fossiliferous limestone that contains oolites and very fine sand; thin dark-gray and brownish-gray shale and dark-gray siltstone beds near base. Thickness about $30 \mathrm{ft}$

Mbn BOONE FORMATION (MISSISSIPPIAN)--Upper unt interbedded light-gray, medium-crystalline, fossiliferous limestone and medlum-gray to brownish-gray chert. M1ddle untt, 0-50 ft thick, brownish-gray, medium-bedded, clayey, very finely crystalline 11mestone; contains many crinoid fragments and some other unidentified fossils. Basal unit persistent sandstone, $0.5-10 \mathrm{ft}$ thick, consists of wel1-rounded, f1ne- to coarse-gralned sand, phosphatic pebbles, glauconite, and pyrite; contains conodonts. Total thickness about $375 \mathrm{ft}$

- 1700 - STRUCTURE CONTOUR DRAWN ON BASE OF UPPER MORROWAN--Contour 1nterval $100 \mathrm{ft}$

U FAULT--U, upthrown side; D, downthrown side; dotted where concealed

- DIRECTION OF DIP OF STRATA

$\longrightarrow$ APPROXIMATE BOUNDARY, ROADLESS AREA APPROXIMATE BOUNDARY, WILDERNESS STUDY AREA AREA OF ZINC AND LEAD POTENTIAL

CONTACT

2n 42 STREAM-SEDIMENT SAMPLE LOCALITY, WILDERNESS

$X$ SS STUDY AREA--Z1nc and lead content in parts per million

Po 0.30 ROCK SAMPLE LOCALITY, WILDERNESS STUDY AREA--

$X$ R17 Z1nc and lead content in parts per million

Pb 30

STREAM-SEDIMENT SAMPLE LOCALITY, ROADLESS AREA--

○ 75 Zinc and lead content in parts per million

Po 20 ROCK SAMPLE LOCALITY, ROADLESS AREA--Z1nc and

- 4R lead content in parts per million

$\leftarrow \rightarrow$ MEASURED SECTION SAMPLE LOCALITY

- DRILL hOLE 
of three units. The basal unit is a sandstone that ranges from $0.5 \mathrm{ft}$ to $10 \mathrm{ft}$ in thickness; it is made up of well-rounded fine to coarse sand, phosphatic pebbles, glauconite, and pyrite, and contains conodonts. The St. Joe Limestone Member, 0-50 ft thick, is the middle unit of the Boone Formation. It is a brownish-gray, medium-bedded, clayey, fine-grained limestone, and contains crinoid fragments. The upper unit is light-gray, medium-crystalline, fossiliferous limestone interbedded with medium-gray to brownishgray chert. In the upper part of the unit the chert becomes very limy and in places grades into siliceous limestone. Some chert is present in nearly all parts of this unit.

The Batesville Sandstone (including the Hindsville Limestone Member), Late Mississippian in age, is exposed in the extreme northern part of the mapped area along Horse and Dry Creeks outside the roadless area. This formation, about $20-40 \mathrm{ft}$ thick, consists of interbedded fossiliferous silty and sandy limestone, silty oolitic limestone, and limy shale. In places the lower part of the Batesville contains angular chert pebbles derived from the Boone Formation.

The Fayetteville Shale, which rests conformably on the Batesville Sandstone, crops out in gentle slopes in the extreme eastern part of the area. About 90 percent of the Fayetteville is dark-gray shale; the rest is dark-gray microcrystalline petroliferous limestone. The middle and upper units of the Fayetteville Shale in this part of northern Arkansas are phosphatic (E. E. Glick, written commun., March 12, 1982). Fossils common in the lower part of the formation are conodonts and pelecypods; the upper part of the Fayetteville contains brachiopods, a few bryozoans, and crinoids. Total thickness of the Fayetteville Shale is $180-220 \mathrm{ft}$ (Glick and Frezon, 1965).

The Upper Mississippian Pitkin Limestone, which conformably overlies the Fayetteville Shale, is exposed in cliffs and steep slopes along streams in eastern and northern parts of the mapped area. Bryozoans, especially the genus Archimedes, crinoids, brachiopods, pelecypods, and corals are common throughout the Pitkin. The lower two-thirds of the formation is medium-gray limestone, mostly massive, containing a few dark-gray limy shale beds. The upper one-third is medium-gray limy shale containing a few limestone beds. Oolites, characteristic of the Pitkin, are abundant in the middle and upper parts of the formation.

Beds of the Morrowan Series rest unconformably on the Pitkin Limestone. The lower Morrowan unit crops out in gentle slopes in the central and southern parts of the area. The lower Morrowan unit locally has a basal channel-fill facies that probably grades into a thin basal conglomerate. In places this channel-fill facies contains as much as $2 \mathrm{ft}$ of oolitic phosphorite. Overlying these rocks is a massive fine-grained sandstone that is about $90 \mathrm{ft}$ thick in the northern part of the mapped area. In the southern part of the area, the lower Morrowan unit contains several limy sandstone beds and some sandy limestone beds. The upper 100$200 \mathrm{ft}$ of the lower Morrowan unit is dark-gray silty shale containing layers of clay ironstone and a few plant fossils (Glick and Frezon, 1965).

The middle Morrowan unit is exposed in cliffs and steep slopes from the southern boundary across the center of the area to the northeastern corner of the mapped area. This unit unconformably overlies the lower part of the Morrowan, or the Pitkin Limestone where lower Morrowan beds are not present. In the southern part of the mapped area, this basal unit is a complex channel-fill facies of conglomerate, sandstone, and shale. The upper 250-300 ft of the middle Morrowan unit is dark-gray shale and fine- to mediumgrained, massive, glauconitic, limy sandstone that locally grades into sandy limestone. Both sandstone and limestone are cross laminated.

The upper Morrowan unit, conformable on the middle Morrowan unit, is made up of crossbedded, massive, fine- to coarse-grained sandstone. These beds cap the higher hills in the roadless area. The upper part of the upper Morrowan unit consists of sandstones, shales, and siltstones; locally these beds contain crinoid stems.

In mapping the Snowball quadrangle, the southwestern part of which covers the roadless area, Glick and Frezon (1965) distinguished the Cane Hill and Prairie Grove Members of the Hale Formation, the Bloyd Shale, and the Atoka Formation. More recent work by E. E. Glick (written commun., March 12, 1982), however, has shown that the Atoka Formation is not present in the area. At his suggestion, the rocks formerly mapped (Glick and Frezon, 1965) as the Cane Hill Member are here shown as the lower Morrowan unit, the Prairie Grove Member and lower Bloyd Shale as the middle Morrow an unit, and the middle and upper Bloyd and the Atoka Formation as the upper Morrowan unit.

\section{SUBSURFACE GEOLOGY}

Rocks of Silurian and Ordovician age, exposed a few miles north and northeast of the roadless and wilderness areas, are present in the subsurface (Glick and Frezon, 1965; Haley and others, 1980). These formations are the Devonian or Silurian Lafferty, Silurian St. Clair and Brassfield Limestones, and Ordovician Cason Shale, Fernvale Limestone, Plattin Limestone, and St. Peter Sandstone. The Ordovician Everton Formation and Powell Dolomite may be present in the subsurface in the area (Glick and Frezon, 1965; Haley and others, 1980).

\section{STRUCTURE}

The Richland Creek Roadless Area is on the northern edge of the Boston Mountains and on the southern margin of the Ozark Dome. The strata in this area are nearly horizontal. Some of the difference in altitude of the base of the Morrowan beds, as indicated by structure contours on the map, may be caused by differential solution and compaction of underlying carbonate rocks. Some of the difference is related to faulting, especially to a major normal fault that extends across the southern part of the area (Glick and Frezon, 1965). Along this fault beds are displaced a maximum of $280 \mathrm{ft}$.

\section{GEOCHEMISTRY}

Nine stream-sediment and two rock samples were collected by the authors from major streams and selected tributaries in or near the Richland Creek Roadless Area. One rock sample (no. 4) is from oxidized sandstone in the upper Morrowan Series, and one 
(no. 1) from shales in the middle Morrowan Series. Haley and others (1980) collected 16 stream-sediment, 3 soil, and 13 rock samples from the Richland Creek Wilderness Study Area. An additional 30 rock samples were collected from a measured section of Bloyd Shale and from the Prairie Grove and Cane Hill Members of the Hale Formation by E. E. Glick (1965).

All stream-sediment samples were sieved, and the minus-50-mesh fraction of each was split and analyzed for 31 elements by a six-step semiquantitative spectrographic method (Grimes and Marranzino, 1968). Haley and others (1980) used the minus-80mesh fraction of samples for spectrographic analyses. All rock samples were analyzed by the same spectrographic method.

Spectrographic analyses of stream-sediment samples from Richland Creek Roadless Area do not show anomalously high metal content in surface formations. Spectrographic analyses of streamsediment samples from Richland Creek Wilderness Study Area (Haley and others, 1980, p. 20-24) also show no anomalously high metal content. Zinc content in samples from all localities ranges from 0 to 260 parts per million (ppm). Although zinc content in some samples is slightly higher than background values, it is not significant. Lead is present in nearly all samples from the Richland Creek Wilderness Study Area and Roadless Area, but its content (as much as $30 \mathrm{ppm}$ ) is not anomalous. These analyses indicate that there are no major areas of mineralized rock at the surface within the two areas.

\section{GEOPHYSICS}

No detailed magnetic or gravimetric surveys have been made of the roadless area. A Bouguer gravity map of Arkansas (Hendricks and others, 1981) shows no anomalous areas within or near the area. Four gravity stations are on or near the boundary of the Richland Creek Roadless Area.

\section{MINING DISTRICTS AND MINERALIZATION}

No current or recent mining activity is evident in or adjacent to the Richland Creek Roadless Area. Past mining activity appears to be limited to claim staking in the late 1800's and early 1900's.

No mining districts lie in or adjacent to the Richland Creek Roadless Area. The nearest mining district, the Cave Creek district, is about $3 \mathrm{mi}$ north of the area. Most of the mining in this district occurred during World War I when about 3,500 tons of zinc concentrates and 1,200 tons of lead concentrates were produced (Stroud and others, 1969). Lead and zinc deposits in this district are related to northeasttrending faults and associated fractures in the Boone Formation (McKnight, 1935). The Boone Formation underlies the roadless area, and faults are present in the southern part of the roadless area (Glick and Frezon, 1965).

No patented mining claims lie within the area. Unpatented mining claims were staked over most of the area between 1889 and 1919 , but no evidence of prospecting or mining activity was found during the field investigation.

In 1981 all but about 660 acres within the area were under lease for oil and gas. Two exploratory oil and gas wells have been drilled adjacent to the eastern boundary of the area; however, no oil or gas was recovered. According to Haley and others (1980), the Batesville Sandstone, Fayetteville Shale, Pitkin Limestone, and middle and upper Morrowan units are possible reservoir rocks for natural gas. The Fayetteville Shale and middle and upper Morrowan units may be sources of shale oil. All these units underlie the Richland Creek Roadless Area.

Oolitic phosphorite occurs in the lower Morrowan unit in some areas (Glick and Frezon, 1965). The phosphorite is too thin and covers too small an area to be considered a resource (J. B. Cathcart, written commun., December 20, 1982). According to Stroud and others (1969), a greater thickness of phosphate rock occurs about $22 \mathrm{mi}$ east of the area. Haley and others (1980) reported phosphorites as much as $2 \mathrm{ft}$ thick in the Fayetteville Shale underlying the area. The lower Morrowan unit is exposed along Falling Water Creek and underlies the Richland Creek Roadless Area at depths as much as $800 \mathrm{ft}$; the Fayetteville Shale is $20-50 \mathrm{ft}$ below the Morrowan beds.

\section{ASSESSMENT OF MINERAL RESOURCE POTENTIAL}

A low potential for zinc-lead deposits exists in the Boone Formation underlying the southern part of the Richland Creek Roadless Area where strata are faulted. The nearest known zinc-lead deposits are in surface exposures of the Boone Formation associated with faulting $3 \mathrm{mi}$ north of the roadless area in the Cave Creek mining district.

On the basis of available information, Richland Creek Roadless Area has a low potential for oil and gas. The Batesville Sandstone, Fayetteville Shale, Pitkin Limestone, and middle and upper Morrowan units may be possible reservoir rocks for natural gas.

The roadless area has a low potential for oil shale from the Fayetteville Shale and the middle and upper units of the Morrowan Series.

\section{REFERENCES CTTED}

Glick, E. E., and Frezon, S. E., 1965, Geologic map of the Snowball quadrangle, Newton and Searcy Counties, Arkansas: U.S. Geological Survey Geologic Quadrangle Map GQ-425, scale $1: 62,500$.

Grimes, D. J., and Marranzino, A. P., 1968, Directcurrent arc and alternating-current spark emission spectrographic field methods for the semiquantitative analysis of geologic materials: U.S. Geological Survey Circular 591, 6 p.

Haley, B. R., Stroud, R. B., and Earhart, R. L., 1980, Mineral resources of the Richland Creek Wilderness Study Area, Newton and Searcy Counties, Arkansas: U.S. Geological Survey Open-File Report 80-354, 29 p.

Hendricks, J. D., Keller, G. R., and Hildenbrand, T. G., 1981, Bouguer gravity map of Arkansas: U.S. Geological Survey Geophysical Investigations Map GP-944, scale 1:500,000.

McKnight, E. T., 1935, Zinc and lead deposits of northern Arkansas: U.S. Geological Survey Bulletin 853, 311 p.

Stroud, R. B., Arndt, R. H., Fulderson, F. B., and Diamond, W. G., 1969, Mineral resouces and industries of Arkansas: U.S. Bureau of Mines Bulletin 645, 418 p. 